\title{
Plant Parasitic Nematodes Associated with Citrus Trees and Reaction of Two Citrus Cultivars to Tylenchulus semipenetrans in Northern Egypt
}

\author{
Abu Habib, A. H. A. ${ }^{1}$, Younes, H. A. ${ }^{2}$, Ibrahim, I. K. A. ${ }^{3}$, Khalil, A.E. ${ }^{4}$ \\ 1\&4) Plant Pathology Institute, Agriculture Research Center (ARC), Alexandria, \\ 2) Agricultural Botany Dept., Faculty of Agric., Saba Basha, Alex. University \\ 3) Plant Pathology Dept., Faculty of Agric., Alex. University
}

\begin{abstract}
A survey of plant-parasitic nematodes (PPN) associating citrus trees in Alexandria, El-Behera and Kafr El-Shiekh governorates, northern Egypt was carried-out during $2017-2019$ growing seasons. A total of 432 root and rhizosphere soil samples were collected from the surveyed citrus trees. Nematodes were extracted using sieving and Bearmann-pan techniques and, identified to the generic level, based on the morphological characters. Besides, the reaction of mandarine, Citrus deliciosa and lime, $C$. aurantifolia against the citrus nematode, Tylenchulus semipenetrans, was determined under greenhouse conditions. Results showed that 9 genera of PPN were found in association with the surveyed citrus trees in the three governorates. The citrus nematode, Tylenchulus semipentrans was found to be very common (frequency of occurrence (FO) $=100 \%$ in all the surveyed locations, followed by the stubby root nematodes, Trichodorus spp., and the lesion nematodes, Pratylenchus spp. The reaction of the two citrus cultivars; Mandarine, Citrus deliciosa and Lime, Citrus aurantifolia to $T$. semipenetrans showed that the two cultivars are susceptible to all the tested populations of $T$. semipentrans with a nematode reproduction factor (RF) was (1.67-2.6). The shoot and root dry weights of these cultivars were reduced as a result of the nematode infection.
\end{abstract}

Key words: citrus nematode, lime, mandarin, reaction, survey

\section{INTRODUCTION}

Citrus is one of the most important economic fruit crops in various regions of the world. So, it has received a great attention in agriculture and industry. In Egypt, citrus has great attention due to its importance for local consumption or exportation to the European countries. Plant diseases caused by soil borne pathogens such as nematode and /or fungi have been considered as major problems in agricultural production throughout the world (Abd-El Gawad et al., 2009). In Egypt, plant parasitic nematodes especially Meloidogyne spp., Patylenchus spp., Tylenchulus semipenetrans, and Xiphinema spp. constitute one of the most important nematode pest groups on many economic fruit crops (Ibrahim et al., 2010).

The nematode of the citric fruits probably infest more than $50 \%$ of the citrus production areas. The losses of the citrus yields caused by these nematodes were estimated to be $\approx 10 \%$ (van Gundy, 1984). Studies on the economic yield losses of citrus trees due to $T$. semipenetrans infection showed that these losses might reach up to $10 \%-30 \%$, depending on the level of nematode infection (Duncan and Cohn, 1990 and Verdego-Lucas and McKenry, 2004). 
Nematode infection of the citrus feeder roots might increase the severity of the drought stress on the citrus trees, and decrease the ability of these roots to uptake water and minerals from the soil. Affected trees have an unthrifty appearance, fewer yields, and smaller fruits, compared to the non-infected trees (Duncan and Cohn, 1990).

The objective of the present work, survey study was to identify phytoparasitic nematodes associated with citrus trees in northern Egypt and estimate the frequency of occurrence and population densities of these nematodes in the collected rhizospheric soil samples and reaction of some citrus cultivars to $T$. semipenetrans.

\section{MATERIALS AND METHODS}

\section{Survey study}

A total of 432 soil and root samples were collected from the rhizosphere of citrus trees showing disease symptoms during the period from 2017 to 2019 from different localities at Alexandria (142 samples), El - Behera (65 samples) and Kafr El-Sheikh (225 samples) governorates, northern Egypt. Soil and root samples were placed in polyethylene bags, and kept in the refrigerator at $4^{\circ} \mathrm{C}$ until nematode extraction within $48 \mathrm{hrs}$. Whenever processed, each sample was thoroughly mixed and rendered for nematode extraction using wet-sieving and Baermann-pan technique (Goodey, 1957; Ayoub, 1980). Plant parasitic nematodes in aliquots of $1 \mathrm{ml}$ of each nematode suspension were placed in Peter's $1 \mathrm{ml}$ eelworm counting slide and the nematode genera were identified and counted with the aid of a compound microscope. The nematodes were identified to the generic level, based on the morphological characteristics of adult and larval forms following the descriptions of Thorne (1961), Goodey (1963) and Mai and Lyon (1975).

\section{Reaction of some citrus species to Tylenchulus semipenetrans}

The reaction of mandarine, Citrus deliciosa and lime, Citrus aurantifolia to $T$. semipenetrans was determined under greenhouse conditions. Citrus seedlings of five months old were planted in $20 \mathrm{~cm}$ diam. prickled polythene bags, containing $4 \mathrm{~kg}$ of steam-sterilized sandy clay soil $(1: 1, \mathrm{v} / \mathrm{v})$ as one seedling/bag. Soil of each bag was infested with $5000 \mathrm{~J}_{2} \mathrm{~s} /$ bag of $T$. semipenetrans the nematode inoculum was added in $10 \mathrm{ml}$ water suspension into four holes around the seedling roots. Non inoculated plants served as control. Nematode treatments and control were replicated 5 times. Bags were arranged in a randomized complete block design on a greenhouse bench and irrigated and fertilized as needed.

Plants were harvested after 180 days of nematode inoculation and assessed for nematode infection. Root systems were carefully washed with a gentle stream of running tap water. Number of $\mathrm{J}_{2} \mathrm{~S}$ in each experimental unit (final nematode population =Pf) was determined and the nematode 
reproduction factor $(\mathrm{Rf}=\mathrm{Pf} / \mathrm{Pi})$ was calculated to determine the host suitability. The tested citrus plants were rated according to their nematode $\mathrm{Rf}$ values, as follows: Plants with $\mathrm{Rf}=0$ were considered as resistant; those with $\mathrm{Rf}=0.1-0.5$ moderately resistant; those with $\mathrm{Rf}=0.6-1.0$ moderately susceptible; those with $\mathrm{Rf}=1.1-5.0$ susceptible; and those with $\mathrm{Rf}>5$ were considered as highly susceptible (Ali, 2005). The fresh and dry weights of the shoot and root systems of the harvested plants were also determined.

Data were statistically analyzed using a computer statistically analysis system (SAS institute Inc., 2000). and means were separated using least significant differences test (LSD)at $P \leq 0.05$.

\section{RESULTS AND DISCUSSION}

Data presented in Table 1 showed the frequency of occurrence (FO) and population density (PD) of plant-parasitic nematode (PPN) genera associating the citrus trees in Alexandria, El-Behera and Kafr El-Sheikh governorates.

Nine PPN genera were found in association with soil and roots of the surveyed citrus trees i.e. Tylenchulus semipenetrans, Trichodorus, Rotylenchus, Helicotylenchus, Aphelenchoides, Tylenchus, Pratylenchus, Tylenchorhynchus and Meloidogyne. The nematode genera; Helicotylenchus, Pratylenchus, Trichodorus and Tylenchulus semipenetrans (Table1). were detected in all the soil samples collected from citrus trees fields.

Soil samples from Alexandria governorate (Abees location) showed that four nematode genera were associating the rhizosphere of citrus trees including Tylenchulus semipenetrans which was the most frequent nematode genus detected with 100\% FO. The nematode genera Tylenchorhynchus and Pratylenchus detected 18-20\% FO followed by Trichodorus (FO= $11 \%$ ). Tylenchulus semipenetrans showed the highest population densities (PD)(2695 nematodes $/ 250 \mathrm{~g}$ soil). On the other hand, the lowest $\mathrm{Pd}$ was recorded for Trichodorus (PD= 11 nematodes $/ 250 \mathrm{~g}$ soil) Table 1 ).

Soil samples of Alexandria governorate (El-maamora location) showed the presence of eight nematode genera in the rhizosphere of citrus trees. Tylenchulus semipenetrans was also the most prevalent with $(\mathrm{FO}=100 \%$ and PD=1105 nematodes $/ 250 \mathrm{~g}$ soil) (Table 1 ).

Five nematode genera were detected in the collected citrus soil samples from El-Behera governorate (Abu Homus location) Tylenchulus semipenetrans was the most prevalent with $(F O=100 \%$ and $P D=6810$ nematodes $/ 250 \mathrm{~g}$ soil). The nematode genera Helicotylenchus and Trichodorus had 10-20\% FO. and PD of $6-23$ nematodes $/ 250 \mathrm{~g}$ soil) (Table 1 ). 
Six nematode genera were detected in the collected citrus soil samples collected from El-Behera governorate (Kafr El-Dawar location) Tylenchulus semipenetrans was also the most prevalent $(F O=100 \%$ and $P D=3560$ nematodes $/ 250 \mathrm{~g}$ soil), flowed by Helicotylenchus and Pratylenchus (FO $=32$ $36 \%$ and $\mathrm{PD}=45-160$ nematodes $/ 250 \mathrm{~g}$ soil) (Table 1 ).

Seven nematode genera were detected in the citrus soil samples collected from Kafr El-Sheikh governorate (Motobus location) Tylenchorhynchus was the most common ( $\mathrm{FO}=100 \%$ and $\mathrm{PD}=7121$ nematodes $/ 250 \mathrm{~g}$ soil). On the other hand, Helicotylenchus, Tylenchorhynchus, Pratylenchus, and Aphelenchoides were the least prevalent $(\mathrm{FO}=1.3-8 \%$ and $\mathrm{PD}=115-204$ nematodes $/ 250 \mathrm{~g}$ soil) (Table 1 ).

Six nematode genera were recovered from the citrus soil samples collected from Kafr El-Sheikh governorate (Fuoa location ) T. semipenetrans was the most common $(F O=100 \%$ and $P D=4021$ nematodes $/ 250 \mathrm{~g}$ soil), followed by Tylenchorhynchus and Trichodorus showed $(\mathrm{FO}=14 \%$ and $\mathrm{PD}=$ 15-92 nematodes $/ 250 \mathrm{~g}$ soil). However, Pratylenchus, Helicotylenchus, and Aphelenchoides were less common with 2-6\% FO and PD of 13-34 nematodes /250g soil. (Table 1).

The survey studies evident that Nine PPN genera were found in association with soil and roots of the surveyed citrus trees, the nematode genera $T$. semipenetrans was the most prevalent with $(\mathrm{FO}=100 \%)$. 
Table (1). Frequency of occurrence (FO) and population density (PD) of plant-parasitic nematode genera associated withcitrus trees in Alexandria, El-Behera and Kafr El-Sheikh governorates

\begin{tabular}{|c|c|c|c|c|c|c|c|c|c|c|c|c|}
\hline \multirow{3}{*}{ Nematode genera } & \multicolumn{4}{|c|}{ Alexandria } & \multicolumn{4}{|c|}{ El-Behera } & \multicolumn{4}{|c|}{ Kafr El-Sheikh } \\
\hline & \multicolumn{2}{|c|}{$\begin{array}{c}\text { Abees } \\
50^{\mathrm{a}}\end{array}$} & \multicolumn{2}{|c|}{$\begin{array}{c}\text { El-maamora } \\
92 \\
\end{array}$} & \multicolumn{2}{|c|}{$\begin{array}{c}\text { Abu Homus } \\
15\end{array}$} & \multicolumn{2}{|c|}{$\begin{array}{c}\text { Kafr El-Dawar } \\
50 \\
\end{array}$} & \multicolumn{2}{|c|}{$\begin{array}{c}\text { Motobus } \\
175 \\
\end{array}$} & \multicolumn{2}{|c|}{$\begin{array}{c}\text { Fuoa } \\
50^{\mathrm{a}}\end{array}$} \\
\hline & $\mathrm{FO}$ & PD & $\mathrm{FO}$ & PD & $\mathrm{FO}$ & PD & $\mathrm{FO}$ & PD & $\mathrm{FO}$ & PD & $\mathrm{FO}$ & PD \\
\hline Aphelenchoides & - & - & 11 & 37 & 22 & 36 & - & - & 8 & 126 & 6 & 34 \\
\hline Helicotylenchus & - & - & 1 & 55 & 20 & 6 & 32 & 45 & 1.3 & 193 & 3 & 13 \\
\hline Meloidogyne & - & - & 6.5 & 20 & - & - & 9 & 135 & - & - & - & - \\
\hline Pratylenchus & 20 & 110 & 7 & 240 & - & - & 36 & 160 & 6 & 204 & 2 & 24 \\
\hline Rotylenchus & - & - & 8.6 & 50 & - & - & - & - & - & - & - & - \\
\hline Trichodorus & 11 & 6 & 7 & 160 & 10 & 23 & 16 & 273 & 12.6 & 289 & 14 & 92 \\
\hline Tylenchorhynchus & 18 & 120 & - & - & - & - & - & - & 4 & 115 & 14 & 15 \\
\hline Tylenchus & . & - & 1 & 10 & - & - & - & - & - & - & - & - \\
\hline Tylenchulussemipenetrans & 100 & 2695 & 100 & 1105 & 100 & 6810 & 100 & 3560 & 100 & 7121 & 100 & 4021 \\
\hline
\end{tabular}

$\mathbf{a}=$ Number of collected samples.

$\mathbf{F O}=($ Number of positive samples/total no. of collected samples $) \times 100$.

PD $=$ Mean number of nematodes $/ 250 \mathrm{~g}$ soil in the positive samples. 
Reaction of two citrus rootstocks to some populations of Tylenchulus semipenetrans:

\section{1- Reaction of mandarine to some populations of $T$. semipenetrans:}

The data presented in Table 2 revealed that mandarine citrus aurantum L. was susceptible to all populations of $T$. semipenetrans, with nematode reproduction factor $\operatorname{Rf}(1.67-2.1)$. Infection with $T$. semipenetrans reduced the shoot and root dry weights of mandarine the die back branch ends were noticed on the arial parts of tested seedlings of mandarine, Citrus deliciosa.

\section{2- Reaction of lime to the some populations of T. semipenetrans:}

Data presented in Table 3 showed that lime, citrus aurantum L. was susceptible to all the tested populations of $T$. semipenetrans where nematode reproduction factor $\mathrm{Rf}$ reached up to 2.1 - 2.29. Infection with $T$. semipenetrans reduced the shoot and root dry weights of Lime seedlings (Table 3).

Table (2). Reactions mandarine seedlings to six populations of the citrus nematode, $T$. semipenetrans, 180 days after inoculations

\begin{tabular}{|c|c|c|c|c|c|}
\hline \multirow{2}{*}{$\begin{array}{l}\text { Nematode } \\
\text { population }\end{array}$} & \multirow{2}{*}{$\begin{array}{c}\text { No. of } \mathrm{J}_{2} s / \text { Bag } \\
(\mathrm{Pf})\end{array}$} & \multirow[b]{2}{*}{ Rf } & \multirow{2}{*}{$\begin{array}{c}\text { Host } \\
\text { Reaction }\end{array}$} & \multicolumn{2}{|c|}{$\begin{array}{l}\text { Dry weight } \\
\text { (g) }\end{array}$} \\
\hline & & & & Shoot & Root \\
\hline 1- Abeis & 10499 a & $2.10 \mathrm{a}$ & $\mathrm{S}$ & $1.35 \mathrm{~d}$ & $0.65 \mathrm{~b}$ \\
\hline 2- El-mamora & $8711 c$ & $1.74 \mathrm{c}$ & $\mathrm{S}$ & $2.00 \mathrm{~b}$ & $0.85 \mathrm{~b}$ \\
\hline 3- KafrEl-Dawar & $9811 b$ & $1.96 \mathrm{~b}$ & $\mathrm{~S}$ & $1.40 \mathrm{~d}$ & $0.53 \mathrm{~b}$ \\
\hline 4- Abu Homus & $9857 \mathrm{~b}$ & $1.97 \mathrm{~b}$ & $\mathrm{~S}$ & $2.00 \mathrm{~b}$ & $0.32 \mathrm{~b}$ \\
\hline 5- Motobus & $9785 \mathrm{c}$ & $1.96 \mathrm{~b}$ & $\mathrm{~S}$ & $1.76 \mathrm{c}$ & $0.71 \mathrm{~b}$ \\
\hline 6- Fuoa & $8795 b$ & $1.67 \mathrm{~d}$ & $\mathrm{~S}$ & $1.44 \mathrm{~d}$ & $0.55 \mathrm{~b}$ \\
\hline Control & - & - & - & $2.9 \mathrm{a}$ & $1.85 \mathrm{a}$ \\
\hline
\end{tabular}

Data are average of 4 replicates each.

Means followed by the same letter (s) in each column are not significantly different at $P \leq 0.05$.

$\mathbf{R f}=$ Final population (Pf) / Initial population $\left(\mathrm{Pi}=5000 \mathrm{~J}_{2} \mathrm{~S} / \mathrm{bag}\right)$.

$\mathbf{S}=$ Susceptible. 
Table (3). Reaction lime seedlings to six populationsof the citrus nematode $T$. semipenetrans, 180 days after inoculation

\begin{tabular}{|c|c|c|c|c|c|}
\hline \multirow{2}{*}{$\begin{array}{l}\text { Nematode } \\
\text { population }\end{array}$} & \multirow{2}{*}{$\begin{array}{l}\text { No. of } \\
\text { J2s/ Bag } \\
\text { (Pf) }\end{array}$} & \multirow{2}{*}{ Rf } & \multirow{2}{*}{$\begin{array}{c}\text { Host } \\
\text { Reaction }\end{array}$} & \multicolumn{2}{|c|}{$\begin{array}{c}\text { Dry weight } \\
\text { (g) }\end{array}$} \\
\hline & & & & Shoot & Root \\
\hline Abeis & $11433 \mathrm{a}$ & $2,29 \mathrm{a}$ & $\mathrm{S}$ & $1.35 \mathrm{~b}$ & $0.35 \mathrm{~b}$ \\
\hline El-mamora & $10286 \mathrm{a}$ & $2.10 \mathrm{a}$ & $\mathrm{S}$ & $1.45 \mathrm{~b}$ & $0.58 \mathrm{~b}$ \\
\hline KafrEl-Dawar & $11189 a$ & $2.24 \mathrm{a}$ & $\mathrm{S}$ & $1.47 \mathrm{~b}$ & $0.58 \mathrm{~b}$ \\
\hline Abu Homus & $10425 \mathrm{a}$ & $2.10 \mathrm{a}$ & $S$ & $1.49 \mathrm{~b}$ & $0.47 \mathrm{~b}$ \\
\hline Motobus & $10913 \mathrm{a}$ & $2.18 \mathrm{a}$ & $\mathrm{S}$ & $1.43 \mathrm{~b}$ & $0.65 \mathrm{~b}$ \\
\hline Fuoa & $10641 \mathrm{a}$ & $2.13 \mathrm{a}$ & $S$ & $1.49 \mathrm{~b}$ & $0.79 \mathrm{~b}$ \\
\hline Control & - & - & - & $2.67 \mathrm{a}$ & $2.5 \mathrm{a}$ \\
\hline
\end{tabular}

Plant-parasitic nematodes especially, the citrus nematode $T$. semipenetrans and the burrowing nematode Radopholus similis are considered among the most important nematode pests in the citrus orchards. These nematodes and other fungus and virus pests play an important role in limiting the productivity of many citrus orchards in Egypt and other parts of the world (Ibrahim et al., 2010).

Nine PPN genera were found in association with citrus trees in Alexandria, El-Behera and Kafr-Elshiekh governorates, Egypt. $T$. semipenetrans, Trichodorus, Helicotylenchus and Pratylenchus were the most prevalents in general. Most of the detected nematode genera were previously recorded on citrus trees in Egypt by other workers (Otiefa, 1955; Otiefa and Tarjan 1965; Ibrahim et al., 2010; Bakr, et al,. 2011).

The citrus nematode $T$. semipenetrans considers common in the orchards of citrus trees in the surveyed governorates. However, Trichodorus, longidorus, Helicotylenchus, Aphelenchoides, Tylenchus, Pratylenchus, Tylenchorhynchus and Meloidogyne showed variable FO and PD values throughout the surveyed locations. These variations could be attributed to the differences existed in the surveyed location, citrus orchards, soil type and time of collecting the soil samples. The detected nematode genera in this study and others were previously found in association with citrus trees in Egypt (Ibrahim, 1994, Radwan and Fatima, 2003; Korayem and Hasabo, 2005; El-Banhawy et al., 2006; Ibrahim, et al., 2010). mandarine and lime seedlings showed a susceptible reaction to all the tested populations of $T$. semipenetrans in this study. (Yousif, 1984; Ibrahim et al. 1985; Haroon and Osman, 2003; Ahmad et al., 2004; Korayem and Hasabo 2005; El-Banhawy et al., 2006; Ibrahim, et al., 
2010; Bakr, et al,. 2011). The infection of mandarine and lime with $T$. semipenetrans led to a significant reduction of shoot and root dry weight of the infected seedlings (Verdejo-Lucas and McKenry, 2004).

\section{REFERENCES}

Abd-El Gawad, M. M. M., Mc Sorely, R. (2009). Movement of citrus nematodeinfested material onto virgin land: detection, current status and solutions with cost-benefit analysis for Egypt. Egypt. J. Agronematol. 7(1): 35-48.

Ahmad, M. S., Mukhtar, T., \& Ahmad, R. (2004). Some studies on the control of citrus nematode (Tylenchulussemipenetrans) by leaf extract of three plants and their effects on plant growth variables. Asian J. Plant Sci, 3(5), 544-548.

Ali, S. F. (2005). Pathological studies on root-knot and cyst nematodes attacking some gramineous crops. M. Sc. Thesis, Faculty of Agriculture, Alexandria University, Egypt. 109 p.

Ayoub, S. M. (1980). Plant nematology: an agriculture training Aid. Nema. Aid.Puplications, Sacramento, California, U.S.A, 195 pp.

Bakr, R. A., Mahdy, M. E., \&Mousa, E. M. (2011). A survey of root-knot and citrus nematodes in some new reclaimed lands in Egypt. Pakistan Journal of Nematology, 29(2), 165-170.

Duncan, L. W., \& Cohn, E. (1990). Nematode parasites of citrus. Plant parasitic nematodes in subtropical and tropical agriculture., 321-346.

El-Banhawy, E. M., Nasr, A. K., \&Afia, S. I. (2006). Survey of predacious soil mites (Acari: Mesostigmata) in citrus orchards of the Nile Delta and Middle Egypt with notes on the abundance of the citrus parasitic nematode Tylenchulussemipenetrans (Tylenchida: Tylenchulidae). International Journal of Tropical Insect Science, 26(1), 64-69.

Goodey, J. B. (1957). Laboratory methods for work with plant and soil nematodes. Tech. Bull. No. 2.Min. Agric. Fish Ed. London. 47pp.

Goodey, J. B. (1963). Soil and fresh water nematodes.New York; John Wiley \& Sons.

Haroon, S. A., \& Osman, E. M. (2003). Nematode presence in Sadat and Tahrir areas with detection of genetic variabilities within root knot nematode population.Assiut J. Agric. Sci., 34: 201-223.

Ibraham, I. K. A., Taha, M. W., \& Hassan, M. W. A. (1985). Resistance of citrus rootstocks to Tylenchulussemipenetrans and Meloidogyne spp. Egypt (abstr). J Nematol, 17, 499.

Ibrahim, I. K. A. (1994). Potentially important phytoparasitic nematodes in agroforesty plantations and the associated host plants.101-109 pp. In: Proc. second Afro-Asian Nematology Symposium. Minufiya, Egypt, December 18-22, 1994. 
Ibrahim, I. K. A., Mokbel, A. A., \&Handoo, Z. A. (2010). Current status of phytoparasitic nematodes and their host plants in Egypt. Nematropica 40:239-262.

Korayem, M., \&Hasabo, S. A. A. (2005). Citrus yield in relation to Tylenchulussemipenetrans in silty loam soil. International Journal of Nematology, 15(2), 179-182.

Mai, W. F. and Lyon H. H. (1975). Pictorial key to genera of plant parasitic nematodes. Cornell Univ. Press, Ithaca, New, York, $172 \mathrm{P}$.

Oteifa, B. A. (1955). Occurrence of citrus nematode in Egypt. Plant Disease Reporter, 33, 989.

Oteifa, B. A., \&Tarjan, A. C. (1965). Potentially important plant-parasitic nematodes present in established orchards of newly reclaimed sandy areas of the United Arab Republic. Plant disease reporter, 49, 596-597.

Radwan, M.A. and Fatma, M. (2003). Root rot disease of citrus root stocks in relation to citrus nematode. Minufiya J. Agric. Res., 28: 1067-1078.

SAS Institute. (2000). SAS users guide. Version 8.1 SAS Inst.,Gary. NC.

Thorne, G. (1961). Principles of nematology.McGraw-Hill Book Company, New York, NY.

Van Gundy (1984). Nematodes. In integrated pest management for citrus. Page (129-131), Riverside, University of Califonoa, U.S.A.

Verdejo-Lucas, S., \&McKenry, M. V. (2004). Management of the citrus nematode, Tylenchulus semipenetrans. Journal of nematology, 36(4), 424-432.

Yousif, G. M. (1984). Differential susceptibility of five citrus rootstocks to Tylenchulus semipenetrans populations. Menia J. Agric. Res. \& Dev. 6 (4), $425-432$. 
الملخص العربي

\section{النيماتودا المتطقلة نباتيًا المصاحبة أثجار الموالح ورد فعل صنفين من الموالح لنيماتودا Tylenchulus semipenetrans فى شمال مصر}

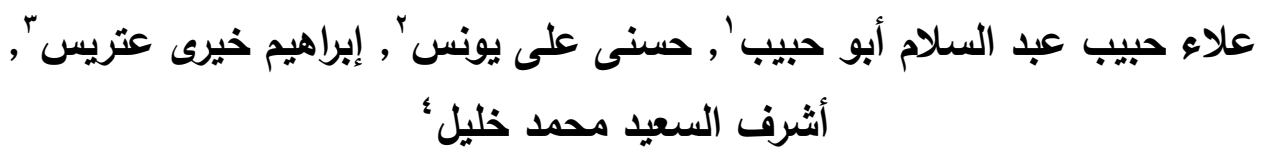
ع, ا) مركز البحوث الزراعية - وزارة الزراعة r) قسم النبات الزراعى - كلية الزراعة سابا باشا - جامعة الاسكندرية r) قسم امراض النيات - كلية الزراعة - جامعة الاسكندرية

تم إجراء حصر للنيماتودا المتطفلة نباتيًا المصاحبة لأشجار الموالح فى ثلاث محافظات بشمال مصر وهى

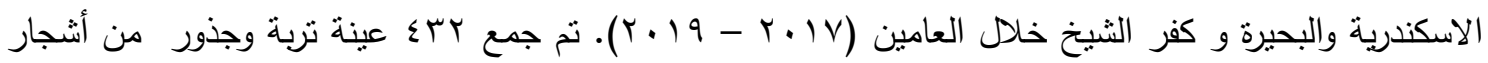
الموالح، وتم استخلاص النيماتودا منها بطريقة المناخل وأطباق بيرمان. أوضحت النتائج نواجد 9 و أجناس من وند

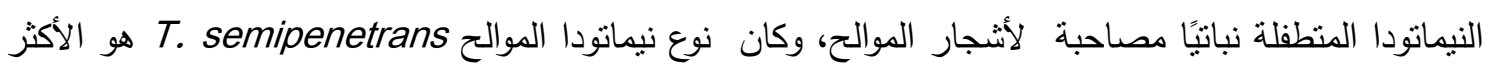

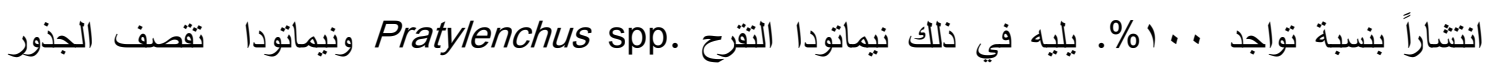
\% منواجدة بنسب 17.0 Trichodorus spp.

semipenetrans Tylenchulus تم تقيم رد فعل صنفين من الموالح وهما اليوسفى والليمون لنيماتودا الموالح

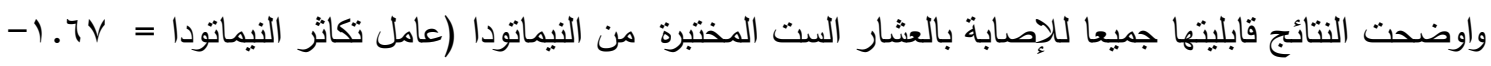

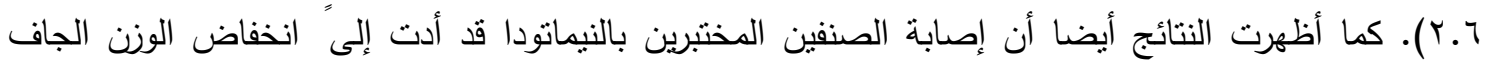
للجذور والمجموع الخضري معنوياً مقارنة بنباتات المقارنة. وفى ضوء النتائج المتحصل عليها يوصى بمكافحة نيماتودا الموالح semipenetrans Tylenchulus بإختيار العوامل الاكثز فاعلية فى مكافحة هذا المرض والموصى بها من وزارة الزراعة وإستصلاح الاراضى. 